\title{
Environmental Indicators for Italian Soils (SIAS Project): Development of a New Approach from Regional to Harmonised National Data
}

\author{
Irene Rischia ${ }^{1 *}$, Marco Di Leginio ${ }^{1}$, Fiorenzo Fumanti ${ }^{1}$, Paolo Giandon ${ }^{2}$, \\ Silvia Obber ${ }^{2}$, Ialina Vinci ${ }^{2}$ \\ ${ }^{1}$ ISPRA - Istituto Superiore per la Protezione e la Ricerca Ambientale \\ Via Curtatone 3, 00185 Roma, Italy \\ ${ }^{2}$ ARPAV - Agenzia Regionale per la Prevenzione e Protezione Ambientale del Veneto, \\ Osservatorio Regionale Suolo, Via Baciocchi 9, 31033 Castelfranco Veneto (TV), Italy
}

Received: 23 January 2010. Accepted: 15 June 2010.

\begin{abstract}
Erosion and loss of organic matter of soils are two of the threats identified by the European Communication "Towards a Thematic Strategy for Soil Protection" (2002/267), and by the Thematic Strategy for Soil Protection (COM 2006, 231). Regarding Italian context, a new approach that exploits soil data and expertise available at local level has been developed in a pilot project, named SIAS Project (Sviluppo Indicatori Ambientali sul Suolo) that involves ISPRA (Italian Institute for Environmental Protection and Research) as project coordinator and financing body, Regional Agency for Environmental Prevention and Protection in Veneto (ARPAV), responsible of the technical coordination of the activities, Regional Soil Survey Services that contribute to the methodology definition and responsible for the data elaboration within their region of the data, JRC and CRA - ABP as technical support.

The SIAS Project concerns the building of two soil environmental indicators, erosion and organic matter content, based on harmonisation of regional data and according with the INSPIRE directive.

The main aim of the SIAS Project can be summarised in exploiting at most the existing information and local expertise for indicator assessment in a relatively short time, in order to obtain interregional harmonisation of the information about erosion and organic matter content at regional scale.

For this purpose, it has been chosen to assess and represent output data by a reference grid $(1 \mathrm{~km} \mathrm{x} 1 \mathrm{~km})$ with a common coordinate reference system, following the recommendations of the INSPIRE Directive. Furthermore an exchange format for storing data and metadata information has been set up jointly by the working group.

So far a large part of the Northern and Central Italy has completed the project, while a part of Southern Region has only recently joined it. The results show that at the present moment there are some differences both in soil loss and in organic matter content assessment among regions, due to several factors such as different availability and resolution of input data, or different methods to assess erosion or parameters required to evaluate organic carbon indicator. At the present stage the scientific coordination group is dealing with collecting and merging these results to obtain a national harmonized pattern of the two indicators. In spite of these problems, the project could be the first step to reach an harmonisation of soil information in Italy periodically updated by regional soil surveys that are the producers and the owners of soil related information in the country.
\end{abstract}

Key-words: soil erosion, Soil environmental Indicators, organic matter content, soil protection.

\section{Introduction}

Soil among natural resources has a primary importance, since most processes governing terrestrial life depend on it. It performs many critical functions in almost any terrestrial ecosystem. Unfortunately, soil is not renewable and because of this a good soil protection policy must be performed. Lately, the European Commission adopted a Soil Thematic Strategy [COM (2006) 231)] and a proposal for a Soil Framework Directive with the objective to protect soils across the EU. Both documents consider 
erosion and organic matter decline as two of the main eight threats leading to soil degradation and require EU Member States to identify areas in their national territory (at the appropriate level) with clear evidence of such threats. Furthermore, the European Commission proposal for a Soil Protection Framework Directive includes the definition of areas at erosion and organic matter decline risk taking into account some basic soil information (Soil Typological Unit, texture, bulk density, hydraulic properties, land use. etc.).

In Italy soil data collection and processing is a regional task and one of the main problems regarding soil assessment is the lack of harmonized data. A new approach that exploits soil data and expertise available at local level has been developed in a pilot project (SIAS - Sviluppo Indicatori Ambientali per il Suolo) which involves 16 Regional Soil Survey Services (not every region has one) out of 20 region, ISPRA (as project coordinator and financing body), ARPAV (responsible for technical coordination of the activities) and the European Soil Data Center (ESDAC, at the EC DG JRC) as technical support and methodology implementation.

In order to assess erosion and organic matter decline risk environmental indicators are introduced. In particular, environmental indicator is a number or a parameter that provides information about an environmental situation or phenomenon. The great advantage in the use of these indicators is that they are simple, objective and comparable in the time and in different areas, and they can be monitored, controlled and verified.

\section{Materials and methods}

\section{Methodology}

SIAS Project has been developed using geographical reference grids and a related database containing data and metadata. The main goal of the project is the assessment of two soil environmental indicators (soil loss SL and organic carbon content OC) through upscaling soil regional data from local to national scale, according to MEUSIS ${ }^{1}$ principles (Multi-Scale Soil Information System). To have a reliable indicator

${ }^{1}$ Fonte: http://eusoils.jrc.ec.europa.eu/projects/MEUSIS/ assessment all factors involved (rainfall, soil, topography, land cover) are evaluated at a detailed scale and information is then upscaled in the final phase, in order to evaluate indicator output values at national level.

The reference grid was provided by ESDAC (European Soil Data Center); the co-ordinate system is the ETRS LAEA system according to the directives for establishing an infrastructure for spatial information in Europe (INSPIRE Directive) and divided into regional grid sections, avoiding any overlapping between bordering regions through the assignment of pixels to the region with the prevalent surface. The grids have $1 \mathrm{~km}$ cell size, which are identified by a unique cell_id and they are provided as ESRI polygon shapefile format.

Regional pixels are described through a shared exchange format containing data and metadata useful to estimate and describe the two indicators. The database includes the following tables related to each other and to the geographic grid:

- PX_TABLE: is the main table and it stores pixel information concerning the indicators, pixel coverage and information quality. The latter involves soil-landscape model knowledge in the pixel together with soil data availability and soil map availability, together with specific confidence level for each indicator in the pixel (OC_CFL and SL_CFL).

- META_SL: it stores data about the model used to assess soil loss, upscaling method, climatic data time range and spazialization method.

- META_OC: it stores information about bulk density measurement or estimation, organic carbon laboratory methods, analytical data standardization converting local methods into ISO methods and OC spazialization procedures.

- META_LC: it stores data about land cover maps (scale and year) used to identify no soil areas and as coverage layer for soil loss assessment.

\section{Soil loss}

Soil loss has been assessed by previsional models which derive both potential and actual erosion. Potential erosion is soil loss evaluated without the attenuating effect induced by land cover which reduces the rain impact on soil and 
slows superficial flow. Actual erosion is obtained by overlaying potential erosion and land cover.

Depending on data input availability (amount and resolution) each Region chose its own method. The empirical model USLE (Universal Soil Loss Equation, Wischmeier and Smith, 1978) or its implementation RUSLE (Revised Soil Loss Equation, Renard et al., 1997) have been the most applied models since they are the most common and experienced ones. Also qualitative models (such as CORINE Erosion, EEA, 1995) have been applied in some cases, due to lack of input information and experimental data, required for more sophisticated model implementation.

USLE/RUSLE model (equation 1) provides quantitative estimates of sediment loss ( $\mathrm{t} / \mathrm{ha} \cdot$ year) by rill and inter-rill erosion caused by water, through overlaying different factors that can be determined from available data

$$
\mathrm{A}=\mathrm{R} * \mathrm{~K} * \mathrm{~L} * \mathrm{~S} * \mathrm{C} * \mathrm{P}
$$

where

$\mathrm{A}=$ mean annual soil loss $(\mathrm{t} / \mathrm{ha} \bullet$ year $)$

$\mathrm{R}=$ rainfall erosivity factor

$\mathrm{K}=$ soil erodibility factor

$\mathrm{L}=$ slope length factor

$\mathrm{S}=$ slope length factor

$\mathrm{C}=$ cover management factor

$\mathrm{P}=$ cultivation practice factor

The assessment of $\mathrm{R}$ factor depends on availability of climatic data; the original Wischmeir formula requires rainfall data at very short temporal range ( $1 / 2$ hour), therefore simplified formulas are very often used.

Soil erodibility factor (K) is usually estimated from data derived from soil surveys through, as for rainfall, complete or simplified formulas. LS factor derives from digital models (DEM) which can have different resolutions while $\mathrm{C}$ factor depends on land use and it is derived from landuse maps.

Potential and actual erosion are obtained by overlaying the different layers (USLE/RUSLE factors) through a GIS, generally starting from detailed scales and then upscaling information to final pixel resolution $(1 \mathrm{~km})$.

\section{Organic Carbon Stock}

Organic carbon stock assessment has been evaluated for three different layers, according to in- ternational reference standards (Good Practice Guidance for Land Use, Land-Use Change and Forestry - LULUCF, 2003, http://www.ipcc-nggip.iges.or.jp/public/gpglulucf/ gpglulucf_contents.htm):

- holorganic horizons (humus), litter excluded. (OC_H);

- between 0 and $30 \mathrm{~cm}$ of mineral soil (OC_30);

- between 0 and $100 \mathrm{~cm}$ of mineral soil (OC_100).

The method to be followed in order to calculate organic carbon stock for each soil profile or Soil Typological Unit (STU) is:

$$
O C=\sum_{1}^{n} o c^{*} b d^{*} t h^{*} \frac{(100-s k)}{100}
$$

where:

$O C=$ organic carbon content in soil profile/STU (t/ha);

$o c=$ organic carbon content in the horizon $(\%)$;

$b d=$ bulk density $(\mathrm{g} / \mathrm{cm} 3)$;

th $=$ thickness of the horizon $(\mathrm{cm})$;

$s k=$ rock fragments $(\%)$

$n=$ number of horizons included in the considered soil profile or STU.

In order to ensure data comparability throughout Europe, organic carbon analytical data have been converted from determination through local methods into ISO methods.

The assessment of organic carbon stock indicator requires the following information layers:

- a soil map with organic carbon data;

- a simplified land use map (CORINE Land Cover 2000 or any other regional land cover map) reclassified as "soil" or "no soil" areas;

- a layer which defines the territory inside and outside the region, the latter specified as "extra-region", "extra-country" or "sea";

- the shape file of the European Reference Grid concerning the region (ETRS LAEA coordinate system).

The three $\mathrm{OC}$ indicators (humus, $0-30 \mathrm{~cm}, 0$ $100 \mathrm{~cm}$ ) are a weighted average of $\mathrm{OC}$ in the $1 \mathrm{~km}$-pixel, derived by a soil map or by a geostatistical approach analysis.

\section{Results and discussion}

So far SIAS Project has collected indicator results of 10 out of 20 Italian regions, most of 
them located in northern Italy and a minor part in central Italy, while most of southern regions have only recently joined the project.

At the present stage, after testing the exchange format and pointing out problems, the technical and scientific coordination group is dealing with collecting, merging and harmonizing first regional results obtaining the national pattern of the two indicators, in order to provide an effective and validated national tool.

\section{Soil loss results}

The present harmonization stage highlighted some differences in soil loss assessment among regions. The two factors that seem to produce the main differences are $\mathrm{R}$ factor (rainfall erosivity) and $\mathrm{C}$ factor (cover management factor). $\mathrm{R}$ factor calculation, according to Wischmeier complete formula, due to detailed rainfall data required, has been applied in few cases and it has been verified that simplified formulas available in literature can lead to very different results. $\mathrm{C}$ factor values are linked to different land uses and reference values can be found in literature or validated in regional specific situations. Differences in $\mathrm{C}$ factor values applied by different regions seem mainly due to lack of harmonization, more than to effective different coverage factors.

Concerning actual soil loss, up to first results, average values range from 2 to $5 \mathrm{t} / \mathrm{ha}$ in the Alps, and from 6 to 23 t/ha in central Italy (Appennini) (Fig. 1).

\section{Organic carbon results}

Since organic carbon indicator output must be expressed as $\mathrm{t} / \mathrm{ha}$, more variables, besides organic carbon content percentage, are involved in the calculation, such as rock fragment content and bulk density, which introduce more uncertainty in the final result. The present harmonization phase is focusing on bulk density, whose estimation is often the main source of not-coherent final results, leading to large differences in stock evaluation. Measured data are always few so that bulk density is often calculated through pedo-transfer functions which estimate fine earth bulk density by means of texture and organic carbon content data. Some regions have derived specific pedo-transfer functions calibrated and validated on their own dataset where large amounts of measurements

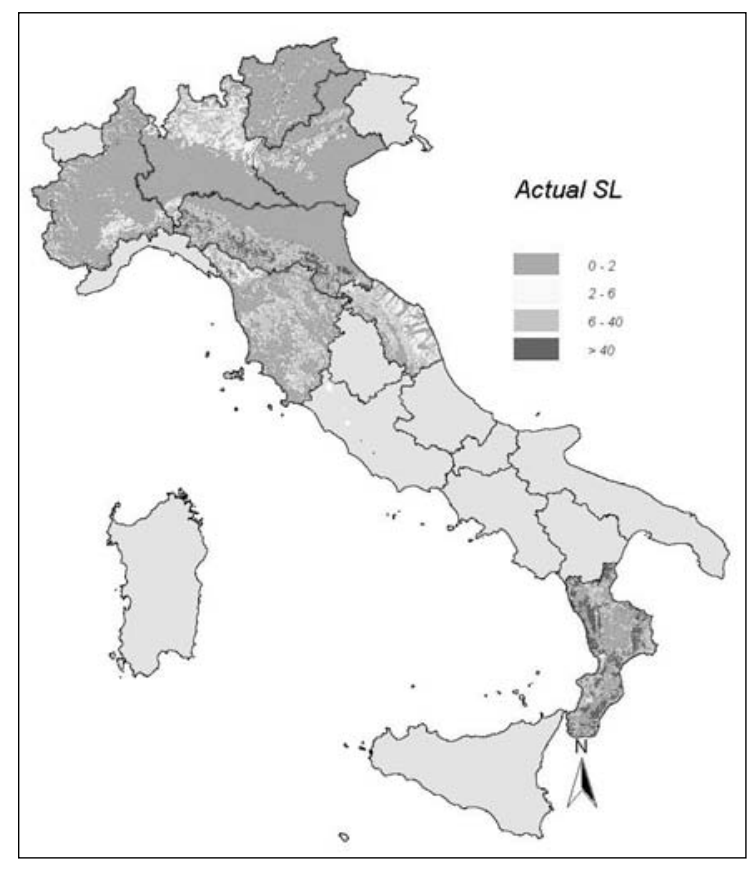

Figure 1. Actual soil loss map.

were available; more often literature pedotransfer functions were used. Bulk density harmonization requires a comparison among selected pedo-transfer function results and measured data, in order to choose the most suitable functions for each environment. Furthermore, it is very important to choose pedo transfer functions which provide different algorithms for different horizon types, since mountain and plain soils are very different concerning compaction, organic carbon content and structure, which are all variables affecting bulk density. There is an ongoing harmonization effort on these issues.

Up to first results, average organic carbon content in plain areas goes from 34 to 60 t/ha in the $0-30 \mathrm{~cm}$ section, with the lowest values in southern Italy (34 t/ha) and the highest (51-60 $\mathrm{t} / \mathrm{ha}$ ) in the north (Po plain) (Fig. 2). Average OC stock in the $0-100 \mathrm{~cm}$ section ranges from 78 to $154 \mathrm{t} / \mathrm{ha}$ in the plain, with the same geographical trend. In the Alps the content is quite variable, going from 59 to $103 \mathrm{t} / \mathrm{ha}$, on average, for the $0-30 \mathrm{~cm}$ section and from 87 to $160 \mathrm{t} / \mathrm{ha}$ for the $0-100 \mathrm{~cm}$. Central and southern mountain areas (Appennini) have average contents of $50-58 \mathrm{t} / \mathrm{ha}$ within $30 \mathrm{~cm}$ and $95-114 \mathrm{t} / \mathrm{ha}$ within $100 \mathrm{~cm}$ (Fig. 3). 


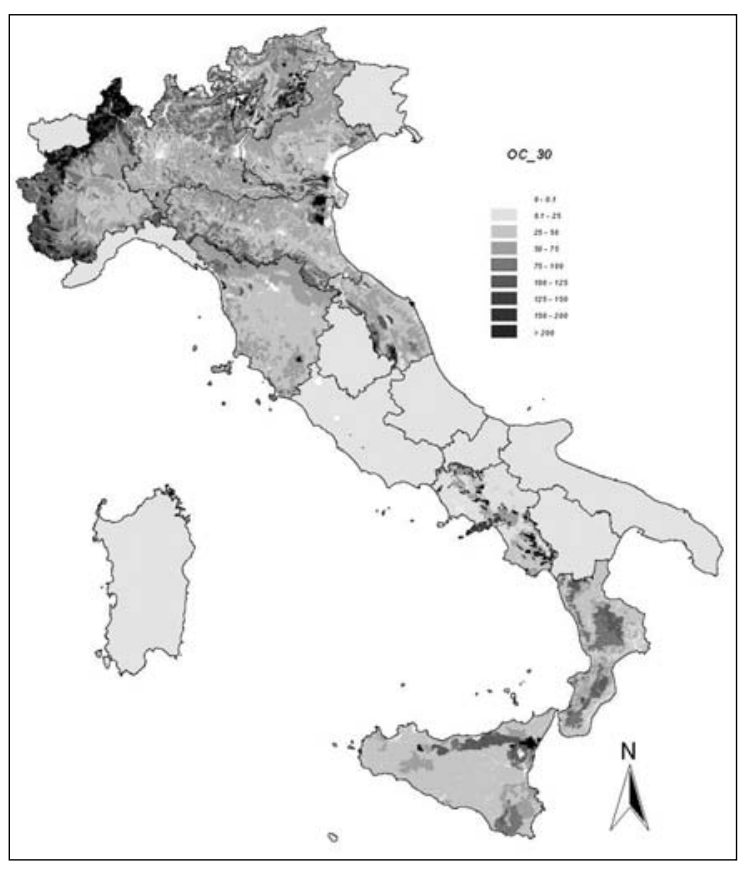

Figure 2. Organic carbon content map in the $0-30 \mathrm{~cm}$ section.

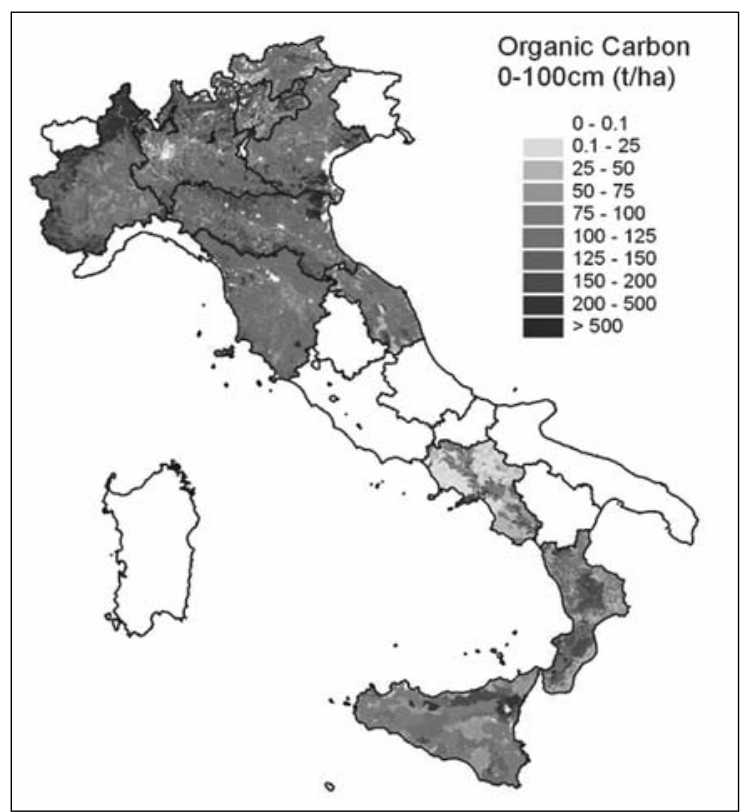

Figure 3. Organic carbon content map in the $0-100 \mathrm{~cm}$ section.

\section{Conclusions}

SIAS Project is the first attempt made to provide consistent information about soil in Italy. It also provides an harmonized assessment tool for the exploitation of local expertise, that is the most suitable level dealing with soil knowledge and soil management. Besides the great practical importance of producing a first set of national indicators which can be used to support national and European level technical decisions, the great meaning of this project lies in the exploitation of local expertise: this can guarantee the use of the most up to date information and the more reliable assessment obtaining a national harmonized and shared result, according to the bottom-up approach. Furthermore the partner cooperation net that has been created in this occasion, can be the ground for other initiatives that will certainly be facilitated by the already set up working group.

Finally, due to the exploitation of European standard reference grids and projection systems, SIAS project results can be used at European scale as the Italian soil erosion and organic carbon content database, to be part of a European database, managed by the European Soil Data Center (JRC) through EIONET.

\section{Acknowledgment}

The authors would especially like to thank all the Regional Soil Service for their valuable cooperation for the outcome of this project.

\section{References}

APAT, 2005. La realizzazione in Italia del progetto europeo Corine Land Cover 2000. Roma, 86 pp.

EEA, 1995. Corine Soil erosion risk and important land resources. http://reports.eea.europa.eu/COR0-soil/en.

European Commission (EC), 2006. Towards a Thematic Strategy for Soil Protection, COM (2002) 267.

European Commission (EC), 2006. Thematic Strategy for Soil Protection, COM (2006) 231.

European Commission (EC), 2007. Directive 2007/2/EC of the European Parliament and of the Council of 14 March 2007 establishing an Infrastructure for Spatial Information in the European Community (INSPIRE). http://inspire.jrc.ec.europa.eu/.

IPPC, 2003. Good Practice Guidance for Land Use, Land-Use Change and Forestry, LULUCF.

MEUSIS-SK: MEUSIS in Italy [online]. DG JRC EC, IES. Available on internet: http://eusoils.jrc.ec.europa.eu/projects/Meusis/italy.html.

Renard K.G., Foster G.R., Weesies G.A., McCool D.K., Yoder D.C. (eds.), 1997. Predicting Soil Erosion by Water: Aguide to conservation planning withe the Revised Universal Soil Loss Equation (RUSLE). Agricultural Handbook N. 703, UDA-SRS, Washington D.C.

Wischmeier W.H., Smith D.D. 1978. Predicting rainfall erosion losses - a guide to conservation planning. Agriculture Handbook N. 537, USDA, Washington. 